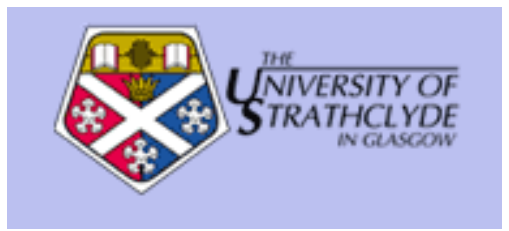

Law, Derek (1994) And another thing...dress codes for book people: L- Librarians. Logos, 5 (2). pp. 105-109. ISSN 0957-9656.

http://eprints.cdlr.strath.ac.uk/2962/

This is an author-produced version of a paper published in Logos ISSN 0957-9656.

This version has been peer-reviewed, but does not include the final publisher proof corrections, published layout, or pagination.

Strathprints is designed to allow users to access the research output of the University of Strathclyde. Copyright (c) and Moral Rights for the papers on this site are retained by the individual authors and/or other copyright owners. Users may download and/or print one copy of any article(s) in Strathprints to facilitate their private study or for non-commercial research. You may not engage in further distribution of the material or use it for any profitmaking activities or any commercial gain. You may freely distribute the url (http://eprints.collr.strath.ac.uk) of the Strathprints website.

Any correspondence concerning this service should be sent to The Strathprints Administrator: eprints@cis.strath.ac.uk 


\section{And another thing... Dress codes for book people: I - librarians}

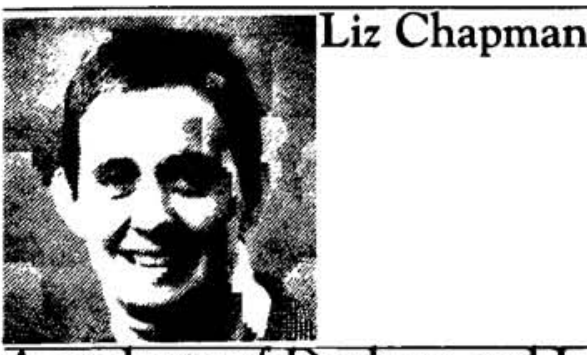

A graduate of Durham and London Universities and of the Polytechnic of North London, Liz Chapman is Librarian of the Institute of Economics and Statistics in the University of Oxford. A fellow of the UK's Library Association and currently a Council member, she is also an active member of the National Acquisitions Group.

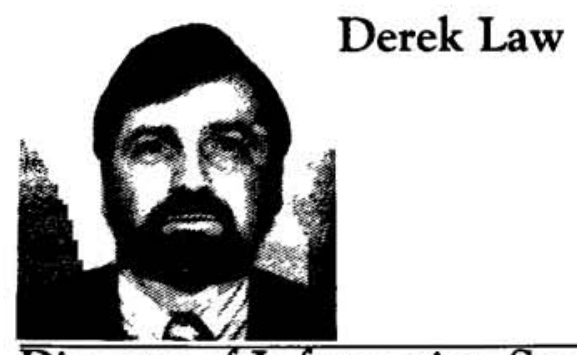

Director of Information Services and Systems at King's College London, Derek Law has worked for twentyfive years in academic libraries. He is a member of the Council of the UK's Library Association and chairs its Executive Committee. A frequent lecturer, Law is the author of over 100 articles, conference papers and books on libraries and related topics.
At a recent meeting of Oxford University's Buildings Committee, two architects attended to give a presentation of their project to alter the entrance of a well-known building. Even before they spoke, it was clear that their dark blue shirts and even darker blue ties were making a sartorial statement about their profession. Proximity to art, but with a hint of formality? Only when we come across such expressions of informal uniform do we realize how revealing dress can be.

Is there, we wonder, an identifiable dress code for the different professions of the book community? Do booksellers tend to wear tweed jackets? Is there really such a thing as power dressing in the executive suites of publishing corporations? Those of us who regularly attend book fairs seem to observe a preponderance of male publishers in pink or checked (or both) shirts topped off with dazzling bow ties. Again there is a suggestion of proximity to art, but in this case a flamboyance which speaks of legendary free lunches and exaggerated blurbs. Some Dutch publishers observed at the last Frankfurt Book Fair wore checked suits as well as checked shirts, but others sported plain jackets in bilious green or half-ripe tomato.

While not trying to imply that all architects or publishers or the members of any other profession all dress alike, there is enough empirical evidence to suggest that this is a subject worthy of research. As a pilot project, we have turned our attention to our own profession - librarians. The rest of the book world - publishers, authors, booksellers, library users, etc - can perhaps commission their own investigations, inspired by the spirit of our observations. We are willing (for free lunches) to do some research on publishers' dress and at the same time compare the comparative effectiveness of bribery and censorship. 
So how do librarians fit into this uniform game? It is not uncommon for library users to ask for library staff to wear a uniform or a badge so that they can be distinguished from library users. This is one of the few requests guaranteed to reduce the mildest of librarians (but only the mildest) to a frenzy, threatening as it does their carefully nurtured chameleon-like ability to fade into the background. Are we not different? Is our uniform as dull as our public image? The following observations about librarians at work and play (conferences) and as portrayed in our professional press are amplified by gratuitous hints on interview and promotion wear.

\section{HAIR}

For men, careful grooming is important, but trips to the hairdresser are not recommended more than monthly. To look too concerned about one's appearance is the ultimate sin. Blacking out the grey is a big no-no, but is done by men who have linked their mid-life crises with new jobs and perhaps new younger-model partners. Pony tails are just permissible in an acknowledged genius (aka guru) or an automation man, but they signal unpromotability. Hairpieces, or even wigs, imply either an unbecoming vanity or a slightly pathetic refusal to acknowledge mortality. There is a disproportionate number of beards amongst male librarians. Most beardless librarians view them with closet Thatcherite disapproval, but know they shouldn't and overcompensate by declaring them $\mathrm{OK}$.

For women, careful grooming is also important, with trips to the hairdresser allowable every six weeks. Male hairdressers, who cannot believe that librarians have anything to talk about, often want to put streaks in the hair to give it "body". They should be discouraged. Hair which is too long gives the appearance of incompetence, since you have obviously not yet grown up. It may get caught in the photocopier or computer printer when you are changing the toner (the equivalent of making the tea in libraries). It is also prevalent amongst the workshy who join libraries for a quiet and shabbily genteel existence. Pony tails imply that you would be happier on a horse. Too short a haircut appears mannish and aggressive. Ungroomed hair implies an untidy mind and incompetent manner. The bun of our popular image is not acceptable, nor is a complicated French plait. This leaves the choice of something nondescript, ie, non-threatening. Mousy is the appropriate shade for all genders.

\section{EYES}

Trendy spectacles are not really acceptable if you want to be promoted, as they imply a "clevererthan-thou" attitude. They may be acceptable for very handsome men. Half-moon glasses can enhance the appearance, particularly when sucked pensively in meetings or opened and closed during a presentation. Glasses are more acceptable on women, but not hanging on a metallic chain around your neck (with a ballpoint also on a second chain). Trendy coloured spectacles are prevalent amongst ladies of uncertain age and a certain size, who wish to demonstrate a welcome jolliness. Taped-up specs are not good for the image. Dark glasses are unacceptable except on prescription, since librarians seldom if ever venture into the sunshine and as a result should not be seen with anything approaching a suntan. (NB. An exception to this pallid regime is certain senior male librarians who are credited with forming the editorial board of the planned Journal of Airport Librarianship.)

Direct eye contact should be avoided with panel members during interviews since it may be taken to imply that you know more about the job than they do. While this is undoubtedly true, panels can assuage their guilt by not appointing you. Equally, direct eye contact with library users can be unnerving for them, since they do not expect confidence from library staff. This is particularly true of elderly professors (ie, any over the age of thirty), who confuse service with subservience. Our popular image usually implies myopia and a lack of confidence, and we must live up to it.

\section{MAKE-UP}

Make-up on women librarians should be very discreet - a little pale lipstick and perhaps some mascara. Bright red lipstick is allowed only at conference dinners, unless you wish to send some very specific and very non-professional signals. Nail varnish is not usually seen, since it chips on the keyboard. Make-up is not allowed for male librarians, at least not those seeking promotion. 


\section{JEWELLERY AND OTHER ADORNMENTS}

Women librarians can get away with small subdued earrings, but long dangling ones are outré. They mesmerize male interviewers, who start wondering where they can be bought and whether they have forgotten their wives' birthdays. Men librarians, except those in the genius category, may not wear even one earring. The piercing and wearing of jewellery in any other (visible) part of the body is not forbidden, but librarians have never heard of such exotica.

Watches should be conservative. The wearing of a $\$ 1$ bright green plastic watch when your own is broken, or one of your children's Thomas the Tank Engine models with the removable lid when you want to tell the time is as ostentatious as fob watches and consequently unacceptable. When worn by management they have the power to shock, since they signal incipient dementia. Even the more or less ubiquitous Swatch betrays a possible link with airports and foreign travel which is faintly suspicious. Bracelets are not allowed for the same reasons as long hair.

Rings carry their own messages. A ring on the left hand ring finger means you are married or in a steady relationship. A very large engagement ring implies that you are only working for pin money as your merchant banker husband keeps you in luxury and you are therefore not seriously committed to librarianship. Women applicants who display their married status are seen as in danger of having children and yards of maternity leave. Women applicants who do not display their married status are seen as in danger of becoming married and of having children, etc.

Men who display their married status are obviously happy and settled and a good bet for promotion, since they will not actually have children. (Men librarians are allowed to bring their school aged children into work over half term, as there are plenty of women at work who can sympathize with this brave attempt at being a new man. Women librarians may not bring their children into work even once as it implies both a lack of professionalism and an out-of-control personal life.)

Very little research has been conducted on the significance of signet rings on men or chest adornment items such as medallions or tattoos, and very little is possible since chests should not be vis- ible. The only known exception is a lecturer in information science in a "new" university. Women may wear quiet but tasteful single strand necklaces and similar rings on their right hands. Brooches may be worn on suit lapels, but should not attract undue attention.

There is no satisfactory place for women to wear identity badges. These are designed by men for men, who have satisfactory places to wear them. It follows that libraries which require the wearing of identity badges are not suitable places for women to work, unless they wish to draw attention to prominent (or not prominent) parts of their anatomy. The wearing of "funny" badges such as "Disturb me" is only acceptable during National Library Week, when the librarian's weak sense of humour is let loose.

\section{TORSO}

For men, shirts should never be too bright, as they run the risk of raising the question of what happened to the rest of the deckchair. (Cf shapeless floral dresses and comments like "we used to have a sofa in that material"). Nice safe stripes or plain white are always best for the ambitious, although a checked shirt worn on a Monday or Friday is regarded as part of a generally tweedy look implying a weekend in the country. Invisible ostentation is allowable. Shirts by Turnbull and Asser rather than Marks and Spencer are always acceptable. So is that odd inch of cuff with discreet cufflinks - especially if they draw attention to not too carefully manicured hands, the mark of the thinker rather than the hornyhanded son of toil.

\section{TIES}

Regimental ties are unacceptable except in the finance department or a department of military studies. Club ties too are de trop. The Garrick implies that one is a dilettante, the Athenaeum that one sucks up to Vice-Chancellors. University ties suggest either a willingness to fawn or that it was the only tie you could find on the one day you had to wear one (interview, royal visit, viva for $\mathrm{PhD}$, etc). Something shapeless and splodgy or striped from the Tie Rack is safest. Bow ties are allowed only to approved eccentrics or to those librarians who also run computing services and perhaps to those associated with the Arts, such as 
music librarians. Bow ties are also useful as a tactic to distract an audience from the fact that one has nothing to say. The ultimate solecism (for men) is, of course, the absence of a tie, which shows the end of ambition. A little discreet loosening of the knot at the Christmas party is allowed, to show just how racy one can be.

\section{BRACES}

Braces are permissible in the young, but must be bright and ostentatious, showing dash, verve and a carefully controlled free-thinking spirit. But they must NEVER be worn without a jacket. To wear functional braces marks one down as quite beyond the pale. The same is true of shirts tucked into underpants, allowed, however, if not approved of, to aspiring Prime Ministers or bachelor librarians who have been of indeterminate age since reaching puberty. Pullovers and cardigans are a sign of woolly-mindedness and non-promotability for men and women, although designer jumpers on the Sunday of a weekend conference may just escape censure. Chief Librarians may wear pullovers on carefully defined casual or social occasions as a statement of their proletarian origins or leanings. The definition of such occasions is full of social pitfalls. One practising librarian defines such times by wearing a hat. When the hat is on, the serious ginger beer drinking may begin.

\section{LEGS}

As with braces, gaudy socks are permissible for the male, if not flashed too indiscreetly. They mark the bearer as a free-thinker and independent spirit, constrained only by the need to feed and clothe the mortgage lender and his family. It goes without saying that you should not have holes in your socks, particularly if you are in the habit of banging your shoe on the table to get attention from your staff at a leaving party. Holes in the soles of shoes are acceptable towards the end of the month as a statement on slave wage rates. Socks should ideally match each other. Women's tights should be flesh coloured or opaque, not bright or shiny. Coloured tights may be worn only for the library Christmas lunch. Thick woollen tights betray a concern for comfort over conformity which is much to be frowned on. Pop socks under skirts which show their tops in the summer are out, although they may be allowed to visiting American or Italian colleagues who are presumed not to know any better.

\section{FEET}

Shoes should be understated for men and very understated for women. Classic Hush Puppies or suede imply the end of ambition. Very high heels are not permissible, as most librarians have to do a lot of walking about looking important with either books or pieces of paper in their hands, and they can get uncomfortable or make holes in the library floor. Doc Martens are unknown. Shoes with metal toe caps or hidden metal inserts in the heels are not permitted as they will trigger the security alarm and wake up the library users. If your feet smell, the same rules apply as for holes in socks (above). Sandals are not permissible for anyone. The single exception is large map librarians with straggly beards who are Ranulph Fiennes lookalikes.

\section{SUITS}

Suits for either gender should cost no more than $£ 100$. For men, Armani-type suits in a dark colour are just possible, but only where age is less than waist size. These should have more buttons than buttonholes visible, with the number of buttonholes in inverse proportion to seniority. Brown suits indicate off-duty mode, but are never acceptable in London (never brown in town). Suits should always look just the right side of shiny and about a year old, even when new. For women, last year's Marks and Spencer classic is acceptable as a suit, or, when slightly less formal, a toning jacket and skirt. As during their previous incarnation in the late ' 60 s, trouser suits may be worn by women if the trousers match the jacket, but you will not be taken seriously while wearing trousers. Formal suits should be softened by delicately flowery blouses. Padded shoulders and power dressing are permitted with some puzzlement in women managers, since, while terrifying to male colleagues, no reason for acceptable disapproval has yet been adduced. Ties should not be worn by women. On serious interview tracks you may have to provide two suits - one for the informal and one for the less demanding formal interview. Men have only to change their shirts and ties. Should they forget, this will either not be noticed or considered endearingly absent-minded. The opposite is true for women. 


\section{JACKETS AND JEANS}

Blazers are out except for the finance department, bursar's department and ex-Regimental Sergeant Majors; they are also sometimes to be found amongst the Directors of the new universities in Britain who want to fit in with what they perceive the Vice-Chancellors' group dress code to be. Sports jackets are completely out for interviews, but are normal working dress outside the "golden triangle" of Oxford, Cambridge and London. Cavalry twill for men, and its female equivalent, crimplene, are old-fashioned and should be avoided, along with corduroy. There is only one occasion when jeans can be worn. Management may squeeze themselves into them while doing the annual emergency desk duty to show how much they are part of the team. As Angela Carter has noted: "Jeans are now, more or less, a sign of grumpy middle age." Leggings are of course a disciplinary offence.

\section{PERFUME}

Librarians are expected to smell as musty as their books. It therefore follows that a distinct perfume or after-shave will be too shocking for library users. A faint whiff of Imperial Leather soap is permissible, since it implies cleanliness and therefore a godliness with faint echoes of the library and its monastic tradition.

\section{UNDERWEAR}

Librarians have never been seen undressed, nor are they ever run over by buses. Therefore underwear does not exist. By the same token, library conferences are rarely held in venues with swimming pools, since swimwear does not exist. When a conference venue with swimming pool is booked by mistake, it is never used by librarians.

We have tried to portray a few of the more obvious of the very complex rules involved in the dress code of librarians. There are still unresearched areas such as overcoats, handbags and umbrellas. For example, one famous character always wore a Pac-a-Mac over his vicuna coat to protect it from the weather. He was known as "George Two Raincoats". We hope this introductory guide will prove useful both to librarians and librarian-spotters. 